\title{
2. A (PRE-)OIL HISTORY OF KUWAIT
}

Kuwait City is not built on sand, as is often claimed. ${ }^{1}$ Rather, the coastal location has been inhabited since the eighteenth century. Therefore, the city's mid-twentieth century urban transformation represents a transition phase within a longer urban history. As a port town of the Arabian Peninsula, Kuwait, like other Gulf states, has historically been considered a border zone of the Arab World, or today the MENA region, and has consequently been understudied. The often scarce archival situation and the demise of much of the pre-oil architecture have enhanced this neglect. ${ }^{2}$ Nevertheless, the history of Kuwait belongs within the transcultural and transregional history of the Persian Gulf, ${ }^{3}$ which, as historian Rosemarie Said Zahlan emphasizes, "is one of the oldest continuously inhabited places in the world." ${ }^{4}$ Kuwait owes its emergence as a successful seaport town to the Gulf as "a key international trade route connecting the Middle East to India, East Africa, Southeast Asia, and China." ${ }^{5}$ Acknowledging Kuwait's dynamic pre-oil history therefore challenges persisting perceptions of the Gulf States as having neither a long history nor, in particular, a long urban tradition; it also allows for a re-situating of the often decontextualized petrofueled urban transformation that has taken place since the late 1940s. In fact, a growing number of recent studies has investigated the modern histories of the Arabian Peninsula

\footnotetext{
1 This superficial assertion is made regarding all Gulf cities, often when comparing cities like Kuwait City to other Arab cities like Damascus or Cairo, or to major European cities; it downgrades material, oral, and archaeological evidence. See for example Shumon Basar, ed., Cities From Zero (London: Architectural Association, 2007); Elisabeth Blum and Peter Neitzke, eds., Dubai: Stadt aus dem Nichts, Bauwelt Fundamente 143 (Basel: Birkhäuser, 2009). For a critique of the Gulf's ahistorical reading see Karen Exell and Trinidad Rico, “There Is No Heritage in Qatar': Orientalism, Colonialism and Other Problematic Histories”, World Archaeology 45, no. 4 (2013).

2 Lawrence G. Potter, "Introduction,” in Potter, The Persian Gulf in History, 1.

${ }^{3}$ Despite the preference of many Arab Gulf states to refer to the waters of the Gulf as the "Arabian Gulf," the region is here referred to as the "Persian Gulf" according to established convention in the historiography of the region in the English language. No political connotation is intended. For a detailed analysis of this politically charged "name game" see ibid., 15-16.

${ }^{4}$ Zahlan, The Making of the Modern Gulf States, 1. A similar description of the Persian Gulf is found in Arnold T. Wilson, The Persian Gulf: An Historical Sketch from the Earliest Times to the Beginning of the 20th Century, rev. ed. (Westport: Hyperion, [1928] 1981).

${ }^{5}$ Lawrence G. Potter, "Introduction," in Potter, The Persian Gulf in History, 1.
} 
and the Gulf through the complex twentieth-century urban trajectories of Gulf cities. ${ }^{6}$ Among these, this book is the first dedicated to the urban visual culture of the Gulf city, in this case Kuwait, as part of a rising petro-modernity in the mid-twentieth century. ${ }^{7}$

\subsection{Kuwait's Pre-Oil History}

Before Kuwait existed as a nation-state, it existed as a town of the same name. Historians generally agree that Kuwait was first settled by the al-'Utūb, a group of families said to be descendants of the 'Aniza tribe. Seeking relief from heavy drought and a difficult political climate, the al-'Utūb emigrated from the Nejd region in the early eighteenth century, first via al-Hasā̄ to al-Zubāra on the Qatar peninsula and subsequently to Kuwait, where they settled in an already existing small fort built by the Banū Khālid tribe.

As early as 1709, Syrian traveler Murtaḍā. 'Alī b. 'Alwān is reported to have stayed in a coastal settlement called al-Kuwayt on his way to Mecca for the hajj. ${ }^{8} \mathrm{He}$ outlined that the name of the town is derived from the diminutive form of al-kūt (fort), hence al-Kuwayt, meaning "small fort." He described a port town with strong trading ties to Basra, one day away by boat; most of the food was imported as the soil was not fertile. He also noted that the architecture was similar to that of al-Hasā' (today's Al Hofuf), but that Kuwait was smaller in size. ${ }^{9}$ Murtaḍās observations capture some of the essential elements of Kuwait's

${ }^{6}$ Among these publications are, for example: Al-Nakib, Kuwait Transformed; Alamira Reem Bani Hashim, Planning Abu Dhabi: An Urban History (Abingdon: Routledge, 2018); Yasser Elsheshtawy, ed., The Evolving Arab City: Tradition, Modernity and Urban Development (London: Routledge, 2008); Yasser Elsheshtawy, Dubai: Behind an Urban Spectacle (London: Routledge, 2010); Yasser Elsheshtawy, ed., Planning Middle Eastern Cities: An Urban Kaleidoscope in a Globalizing World (London: Routledge, 2010); Nelida Fuccaro, Histories of City and State in the Persian Gulf: Manama since 1800 (Cambridge: Cambridge University Press, 2009); Claudia Ghrawi, "A Tamed Urban Revolution: Saudi Arabia's Oil Conurbation and the 1967 Riots," in Violence and the City in the Modern Middle East, ed. Nelida Fuccaro (Stanford: Stanford University Press, 2016); Stefan Maneval, New Islamic Urbanism: The Architecture of Public and Private Space in Jeddah, Saudi Arabia (London: UCL Press, 2019); Menoret, Joyriding in Riyadh.

7 The only exception to this is Mona Damlujis PhD thesis on documentary films, which however only focuses on oil company commissioned film productions. See Damluji, "Petroleum's Promise." The urban visual culture of Iran, another petro-state, in general (i.e., without a particular focus on petroleum) has been explored in two notable publications: Pamela Karimi, Domesticity and Consumer Culture in Iran: Interior Revolutions of the Modern Era (London: Routledge, 2013); Staci G. Scheiwiller, ed., Performing the Iranian State: Visual Culture and Representations of Iranian Identity (London: Anthem, 2013).

${ }^{8}$ Ulrich W. Haarmann has been able to show that this source-and not, as assumed until then, the travel accounts of Carsten Niebuhr-contains the earliest mention of Kuwait. See Ulrich W. Haarmann, "Early Sources on Kuwait: Murtaḍā b. 'Alī b. 'Alwān and Carsten Niebuhr: An Arab and a German Report from the Eighteenth Century," Hadith al-Dār 3 (1995); Ulrich W. Haarmann, “Two 18th-Century Sources on Kuwait: Murtaḍā b. 'Alī b. 'Alwān and Carsten Niebuhr," in Slot, Kuwait.

9 Ulrich W. Haarmann, "Two 18th-Century Sources on Kuwait: Murtaḍā b. 'Alī b. 'Alwān and Carsten Niebuhr," in Slot, Kuwait, 37-39. Haarmann provides a translation of the original Arabic text. 
pre-oil lifeworld: while the locality was not particularly blessed in terms of local produce, lacking good water supplies, wood, and farmable land, it was endowed with a favorable natural harbor in a suitable strategic location, which the formerly pastoral nomads put to good use by becoming seamen trading with Basra and many other places. Murtaḍa also mentioned Kuwait's alternative name al-Qurayn (sometimes written as Grain or Grän). Later, Lewis Pelly, the Political Resident of the Persian Gulf (1862-1872), suggested that the name al-Qurayn derived "from Gern, a horn, which the bay is said to resemble in shape." ${ }^{10}$ In fact, the name is the diminutive form of qarn, Arabic for horn.

The name al-Qurayn was frequently used in European documents, for example those of the German cartographer Carsten Niebuhr, who provided another pivotal, although second-hand account of Kuwait dating from the second half of the eighteenth century. ${ }^{11}$ Niebuhr, who located Kuwait on a map of the Persian Gulf, described the location by referencing both of its names: "Koweit s[ive] Grän" (Koweit/Kuwait equaling Grän/alQurayn). ${ }^{12}$ Kuwait was thus first known as a settlement with a small fort at a horn-shaped bay.

To the east, the town of Kuwait was delineated by the Persian Gulf. From the northwest to the southwest, mostly flat desert surrounded the settlement; as one traveler noted in the 1830 s, "nothing is to be seen but vast sandy plain, extending to a distance of more than sixty miles. Not a tree, not a shrub affords the eye a momentary relief." ${ }^{13}$ While framed on one side by a waterfront and natural harbor, landward Kuwait used to be enclosed by a wall that, together with its subsequent extensions, decisively shaped the town's urban morphology. It is assumed that Kuwait's first wall was built during the reign of the first ruler, Shaykh Sabah I (d. 1762), around 1760 or earlier, which indicates that the Al Sabah (Āl Șabāh), which continue to rule Kuwait today, already held some authority over the affairs of the town at the time. ${ }^{14}$ The wall was built to protect the settlement against sand storms and hostile intruders like the Wahhabi raiders, who attacked it in 1793 and 1797,

${ }^{10}$ Lewis Pelly, Report on a Journey to Riyadh in Central Arabia (1865), repr. ed. (Cambridge: Oleander, [1866] 1978), 10.

${ }_{11}$ Niebuhr, a mathematician and civil servant, participated in the orient expedition of the Danish King Frederick V in 1761 and returned six years later. He then published his geographical manual as Beschreibungen von Arabien (1772) and his first-hand experiences in Reisebeschreibungen nach Arabien (1774, 1778, and 1837), in which he wrote about Kuwait, a city he had in fact never visited. Carsten Niebuhr, Beschreibung von Arabien: Aus eigenen Beobachtungen und im Lande selbst gesammleten Nachrichten abgefasset (Copenhagen: Nicolaus Möller, 1772), 341-42; For a discussion of Niebuhr and Kuwait see Ben J. Slot, The Origins of Kuwait (Leiden: Brill, 1991), 69-100, 103-8.

12 As detailed in Niebuhr's map of the Sinus Persicus, 1764, Niebuhr, Beschreibung von Arabien, plate xix.

${ }^{13}$ Joachim Hayward Stocqueler, Fifteen Months' Pilgrimage Through Untrodden Tracts of Khuzistan and Persia: In a Journey from India to England, through Parts of Turkish Arabia, Persia, Armenia, Russia, and Germany; Performed in the Years 1831 and 1832 (London: Saunders \& Otley, 1832), 18.

${ }_{14}$ Kuwait's first ruler was Abū 'Abdillāh Șabāḥ I bin Jābir Āl Șabāḥ (ca. 1700-1762), who reigned from 1752 to 1762 . Facey and Grant suggest that the wall was constructed before 1760; see William Facey and Gillian Grant, Kuwait by the First Photographers (London: I. B. Tauris, 1999), 8. Abu-Hakima and Al-Nakib give the 
but also to control the movement in and out of the town, thereby managing the collection of customs. ${ }^{15}$ Carsten Niebuhr reports that, in the second half of the eighteenth century, Kuwait had eight hundred ships and, when all had returned from their maritime voyages and caravan journeys, around ten thousand inhabitants. ${ }^{16}$

During the rule of Sabah's son Abdallah I (r. 1763-1814), the Al Sabah began focusing exclusively on the government of the town and no longer participated in trade. ${ }^{17}$ In exchange for their supervision, the other large merchant families provided sustenance for the Al Sabah, creating a system of mutual dependence with the majority of power in the hands of the merchants. ${ }^{18}$ Until the mid-twentieth century, the higher strata of Kuwait's society consisted of the ruling family and the merchant families, of which a few very wealthy families owned most of the ships and the larger number were small shop owners. There were also the sailors that seasonally worked on the boats as well as Bedouin herdsmen and traders; these made up most of the pearl divers and also contributed to the defense of Kuwait during times of conflict by providing men for the armed forces. ${ }^{19}$ The sailors, herdsmen, and divers lived in the town only seasonally or visited irregularly and belonged to the lower social strata. Overall, the majority of Kuwaitis were involved in a maritime economy consisting of fishing, pearl diving, shipping, shipbuilding, and trade..$^{20}$ All groups were tied together in a complex system of debt caused by the nature of the pearling economy, which some authors argue created a strong (and rather supportive) network, but others reject as exploitative. ${ }^{21}$

year 1760; see Ahmad Mustafa Abu-Hakima, The Modern History of Kuwait: 1750-1965 (London: Luzac, 1983), 7; Al-Nakib, Kuwait Transformed, 22.

${ }_{15}$ Abu-Hakima, The Modern History of Kuwait, 46-47, 59; Facey and Grant, Kuwait by the First Photographers, 8.

${ }^{16}$ Niebuhr, Beschreibung von Arabien, 341-42.

${ }^{17}$ Kuwait's second ruler was 'Abdullāh I bin Ṣabāh Āl Ṣabāh (1740-May 3, 1814).

${ }^{18}$ Jill Crystal, Oil and Politics in the Gulf: Rulers and Merchants in Kuwait and Qatar (Cambridge, UK: Cambridge University Press, 1990), 36-45; Eran Segal, "Merchants' Networks in Kuwait: The Story of Yusuf al-Marzuk," Middle Eastern Studies 45, no. 5 (2009); Suhail Shuhaiber, "Social and Political Developments in Kuwait Prior to 1961," in Slot, Kuwait, 100.

${ }_{19}$ Suhail Shuhaiber, "Social and Political Developments in Kuwait Prior to 1961," in Slot, Kuwait, 102-4; Farah Al-Nakib, "Revisiting Hadar and Badū in Kuwait: Citizenship, Housing, and the Construction of a Dichotomy," International Journal of Middle East Studies 46, no. 1 (2014): 8; Robert S. Fletcher, "Between the Devil of the Desert and the Deep Blue Sea': Re-orienting Kuwait c. 1900-1940," Journal of Historical Geography 50 (2015): 54.

${ }^{20}$ Frank Broeze, "Kuwait Before Oil: The Dynamics and Morphology of an Arab Port City," in Gateways of Asia: Port Cities of Asia in the 13th-20th Centuries, ed. Frank Broeze, Comparative Asian Studies Series 2 (London: Kegan Paul International, 1997), 152.

${ }^{21}$ Among the authors who describe pre-oil Kuwait's social structure as mutually supportive are: Farah Al-Nakib, "Inside a Gulf Port: The Dynamics of Urban Life in Pre-Oil Kuwait," in The Persian Gulf in Modern Times: People, Ports, and History, ed. Lawrence G. Potter (New York: Palgrave Macmillan, 2014), 204-7; Suhail Shuhaiber, "Social and Political Developments in Kuwait Prior to 1961," in Slot, Kuwait, 103. Those 
Stimulated by maritime activities and trade, the town grew larger, and a second wider wall was built in 1811; this new wall "reflected the extent of the town's achieved and anticipated spatial expansion." ${ }^{22}$ English traveling journalist Joachim Hayward Stocqueler, who spent a few nights in Kuwait in April 1831 on his ship passage from Bombay to the Shatt al Arab, found the town - which now had over twenty thousand inhabitantsdisappointing, being so "sterile, it literally yields nothing." ${ }^{23}$ Lewis Pelly, however, stated upon his visit in 1865 that despite the lack of sweet water, "Kowait [sic] is one of the most thriving ports in the Persian Gulf. Its craft are large and numerous, trading with India and the Arabian coast." ${ }^{24}$ He reported that Kuwaiti merchants imported a wide array of goods such as rice, corn, dates, timber, wool, horses, coffee, and tobacco. ${ }^{25}$

Attention for Kuwait increased during the second half of the nineteenth and the early twentieth century due to imperial interest in securing influence over (the port of) Kuwait. In 1871, Kuwait came under Ottoman rule as a kaza of Baghdad, a provincial sub-district, and thus formally integrated into the Ottoman Empire, eventually becoming part of a new administrative province, the vilayet Basra. Claiming power in 1886, Shaykh Mubarak, who is considered "the founder of modern Kuwait," strove to gain confirmation as the ruler (kaymakam) of this kaza. ${ }^{26}$ However, as Ottoman recognition was a long time in coming, Mubarak turned to another foreign power eager to increase its presence in the Gulf, the British, for protection and alliance, asking for the establishment of a British protectorate in Kuwait in $1897 .{ }^{27}$ In The Ottoman Gulf, Frederick F. Anscombe shows that the immediate period after Mubarak's claim of power was a clever time to play the Ottomans against the British and vice versa for Mubarak's own benefit. Despite Kuwait's nominal status as a part of the Ottoman empire and Mubarak's eventual recognition as kaymakam, he signed a secret "nonalienation bond" with Britain in 1899 that secured him protection and more independence from the Ottomans, especially as the British did not firmly exert their rule. However, the bond stipulated that Kuwait would only maintain relationships with other countries through Britain or with British approval, with Britain's interference supposedly

who describe the debt system as exploitative are Khalaf and Hammoud, "The Emergence of the Oil Welfare State," 345-48.

22 Al-Nakib, Kuwait Transformed, 22.

${ }^{23}$ Stocqueler, Fifteen Months' Pilgrimage Through Untrodden Tracts of Khuzistan and Persia, 19 (italics in the original). On the number of inhabitants see Suhail Shuhaiber, "Social and Political Developments in Kuwait Prior to 1961," in Slot, Kuwait, 101.

${ }^{24}$ Pelly, Report on a Journey to Riyadh in Central Arabia (1865), 10.

25 Ibid.

${ }^{26}$ Mubārak Ṣabāh II al-Jābir I Āl Ṣabāh (1839-November 28, 1915) ruled Kuwait from 1896 to his death in 1915. See Ben J. Slot, Mubarak Al-Sabah: Founder of Modern Kuwait 1896-1915 (London: Arabian Publishing, 2005).

${ }^{27}$ Frederick F. Anscombe, The Ottoman Gulf: The Creation of Kuwait, Saudi Arabia, and Qatar (New York: Columbia University Press, 1997), 101. Anscombe explains the treaty's special nature: "in practice the primary difference between a bond and a protectorate was that the former could be better kept secret." Anscombe, The Ottoman Gulf, 111-13. 
constrained to foreign policy only. From the British point of view, this treaty prevented the Germans, an Ottoman ally, from having the Baghdad railway terminate in Kuwait, the best port of the Persian Gulf, and hence from gaining more strategic presence in the region. The Persian Gulf was precious to the British for its status as best gate to reach its "crown jewel" India. Interestingly, the exact scope of the treaty remained secret until 1912 and the status of Kuwait as "quasi-protectorate" stayed intact until independence despite many debates about its nature. ${ }^{28}$

Travel reports are one of the most valuable sources on the pre-oil history of Kuwait. They provide first-hand information in text and, often, images, about the urban conditions, lifestyles, and connectedness of Kuwait. For example, in December 1903, the German scholar and traveler Hermann Burchardt took a būm (wooden boat) from Basra to Kuwait and, upon his arrival, Shaykh Mubarak invited him to stay at his palace. The traveler acknowledged that his room was equipped with a mattress and bed linen as well as a towel and a piece of German soap. ${ }^{29}$ He experienced Kuwait as a "very expansive city, certainly numbering 30,000 inhabitants, whose streets are kept clean. As I noticed, they are regularly swept and sprinkled in the early morning. The Shaykh inspects the city several times daily in a coach or on horseback." ${ }^{30}$ Three years later Alfred Stürken, a German merchant from Hamburg, arrived on a steamboat of the British India Steam Navigation Company, which had begun calling at Kuwait every two weeks. He provided observations similar to Burchardt's on the city's cleanliness and emphasized the impressiveness of Kuwait's wharves, where many of the dhows sailing the Persian Gulf were built. ${ }^{31}$

Stopping in Kuwait in 1912, Danish writer and explorer Barclay Raunkiær similarly described a bustling port town, which by this time had grown to include a two-kilometer coastline and had a landward width of no more than one kilometer. He listed in great detail that while Kuwait exported pearls, wool, salted sheep meat, and goat skins, it imported basically everything else, including wood, butter, charcoal, fruit, sugar, tee, matches from Austria and Sweden, and coffee pots from Al Hofuf and Baghdad. Notably, the white cotton fabric used to tailor the men's dishdasha, the most important piece of male clothing, came via Aden all the way from a company in Boston, while other colored cotton fabrics arrived from England. ${ }^{32}$ Given Kuwait's magnitude of regional and international exchange, Raunkiær concluded that "Kuwait is the most important trading town on the east coast of Arabia," both for caravan trade with central Arabia and Iraq and seaborne

\footnotetext{
28 Anscombe, The Ottoman Gulf, 113.

${ }^{29}$ Hermann Burchardt, “Ost-Arabien von Basra bis Maskat auf Grund eigener Reisen," Zeitschrift der Gesellschaft für Erdkunde zu Berlin, no. 21 (1906): 207; reprinted in Nippa and Herbstreuth, Along the Gulf (Berlin 2006), 203-27.

30 Ibid.

${ }^{31}$ Alfred Stürken, "Reisebriefe aus dem Persischen Golf und Persien," Mitteilungen der Geographischen Gesellschaft in Hamburg 22 (1907): 92.

32 Barclay Raunkiær, Through Wahhabiland on Camelback (1913) (New York: Frederick A. Praeger, 1969), 33-51 (on Kuwait), here 44.
} 
trade with Iraq, Persia, India, East Africa, and East Arabia. ${ }^{33}$ The Gulf was now also served by the Hamburg-America-Line and some other English ship lines, but only British-Indian shipping companies such as the British India Steam Navigation Company were allowed to call at Kuwait, which by then the company did weekly. ${ }^{34}$ The town of Kuwait was clearly a dynamic, bustling, and well-connected coastal settlement even prior to the arrival of oil production. Transregional trade was already common, and the livelihood of Kuwait depended on these exchanges of produce, pointing to not only a certain boldness required to strive in such an environment but also to the ecological fragility of the setup.

Until the early twentieth century, the town of Kuwait experienced more or less continuous economic stability, steady urban growth, and peace. Due to a peak in pearling from increased, mostly Western, demand in luxury goods such as pearls and motherof-pearl, the period between the 1890s and the year 1920 was the most prosperous. ${ }^{35}$ Profiting from the geopolitical assets of location and its fine natural harbor, Kuwait also thrived due to its strategic political maneuvering between regional and imperial powers. This negotiating was aimed at securing Kuwait's independence and political neutrality as much as possible. ${ }^{36}$

In sharp contrast, the 1920s and 1930s heralded a phase of great economic hardship, galvanized by several events colliding at once. Abdul Aziz ibn Saud, then emir of Nejd, attacked Kuwait at Jahra, an oasis village to the northeast, in October 1920 and continued raids on Kuwaiti territory until 1930. Just a little earlier, the third, last, and longest town wall was constructed that delineated and shielded the town of Kuwait to a certain extent. ${ }^{37}$ With the British-mediated Uqair Protocol in 1922, Kuwait lost two thirds of its territory to the Nejd (today part of Saudi Arabia). From 1923 to 1937, Ibn Saud imposed an embargo on Kuwait due to a customs dispute and consequently deprived Kuwait's harbor of its historic role of providing Eastern Arabia with everyday goods and transportation. Moreover, Japan successfully brought the first cultured pearls to market in the late 1920s against the background that the economic depression that had followed World War I culminated in the Great Depression. Consequently, the demand for Gulf pearls decreased and the value of natural pearls declined heavily, and so did pearl fishing in the Persian Gulf. ${ }^{38}$ Pearls and with them the pearl merchants were left without a market; and without their circulation, the commodity pearl became useless and even ruinous.

When Alan Villiers, an acclaimed Australian photojournalist and experienced seaman, visited Kuwait in 1939, pearling was heavily on the decline, with some of the

${ }^{33}$ Ibid., 46.

34 Ibid., 44.

35 Al-Nakib, Kuwait Transformed, 23, 27-28.

${ }^{36}$ Abu-Hakima stresses this factor throughout his book. See Abu-Hakima, The Modern History of Kuwait.

${ }^{37}$ Ibid., 133 and fn. 11. Al-Nakib emphasizes that it was not built to ward off Bedouin raiders, as is sometimes insinuated in popular Kuwaiti discourse, see Al-Nakib, "Revisiting Haḍar and Badū in Kuwait," 8-10.

${ }_{38}$ Bowen, "The Pearl Fisheries of the Persian Gulf," 164; Dickson, The Arab of the Desert, 484; Zahlan, The Making of the Modern Gulf States, 22. 
pearling merchants' houses abandoned and derelict. ${ }^{39}$ At that time, Kuwait consisted of around eight thousand houses and seventy thousand inhabitants; Villiers reported that only onehundred-and-fifty boats of all kinds and sizes had gone out that year, while forty years ago they would have numbered six hundred. ${ }^{40}$ Historian Robert S. G. Fletcher asserts that "amidst the general crisis of the pearl trade between the wars, it was the desert and its opportunities that helped the state survive into the oil age." ${ }^{41}$ As a result of these events, Kuwait's maritime economy shrunk and was subsequently reduced to deep-sea carrying trade and shipbuilding only. Against this background, the discovery of massive oil deposits in an area of the desert called Burgan on February 22, 1938, stirred high hopes for relief from economic hardship but also offered a chance to reconnect with Kuwait's rather cosmopolitan, mercantile, and dynamic recent past.

In light of early twentieth-century descriptions of Kuwait's prosperity, later assessments of the town as stagnant on the eve of oil production, only a few decades later, are surprising. They reveal an ideological bias toward an oil-based economy. An article in National Geographic, for example, explained: "Kuwait, the former sleepy village, has awakened with the coming of oil and is stretching its strong new limbs." ${ }^{22}$ Such comments remain superficial given the extremely successful entrepreneurship of Kuwaitis over the centuries in an utterly hostile environment. Yet, they reflect the prevailing logic of modernization and development theories at the time, which used orientalist tropes to exacerbate the "positive" impact of the petro-industry to advance the "developing" world.

\subsection{Oil Industrialization in Kuwait and the Persian Gulf}

From the mid-twentieth century onward, the oil boom around the Persian Gulf created a new epicenter of international attention, with Kuwait at its center. Yet the country was not the first in the region to strike oil. On the Iranian side of the Persian Gulf, oil in

\footnotetext{
${ }^{39}$ Pearling was not only centered on the pearls themselves but also on the oyster shells. Therefore, as Kate Lance has argued, the decline of the pearling economy in the Persian Gulf was caused not only by the invention of the cultured pearl in Japan (as Villiers thought and what is still commonly argued), but from Japanese industrialized ships fishing en masse for pearl shells in Australian waters. Furthermore, (luxury) products like buttons made from mother-of-pearl were increasingly substituted by (petroleum-based) plastic imitating the iridescent sheen, such as pearloid. See Kate Lance, Alan Villiers: Voyager of the Winds (London: National Maritime Museum, 2009), 163.

${ }^{40}$ Alan Villiers, Sons of Sindbad: An Account of Sailing with the Arabs in Their Dhows, in the Red Sea, round the Coasts of Arabia, and to Zanzibar and Tanganyika; Pearling in the Persian Gulf; and the Life of the Shipmasters and the Mariners of Kuwait, rev. ed. (London: Arabian Publishing, [1940] 2006), 313, 324; on pearling in general see 324-47.

${ }^{41}$ Fletcher, "Between the Devil of the Desert and the Deep Blue Sea," 65; on the "profound crisis" of the 1920s and 1930 s see $57-60$.

${ }^{42}$ Paul E. Case, "Boom Time in Kuwait," National Geographic Magazine 102, no. 6 (December 1952), 802 (author's emphasis); photographs by George Rodger.
} 
massive quantities was first discovered in Masjed Soleyman as early as 1908. This resulted in the establishment of the London-based Anglo-Persian Oil Company (APOC) in 1909, which was renamed the Anglo-Iranian Oil Company (AIOC) in 1935 and finally British Petroleum (BP) in $1954 .{ }^{43}$ In 1913, the British-run Persian oil industry started from a newly built refinery at Abadan, which became the oil center of the Gulf for the first half of the twentieth century. On the Arabian side, the first successful oil well tapped the black gold at Baba Gurgur near Kirkuk in British-mandated Iraq in 1927 and at Jebel Dukhan, Bahrain, in 1931; oil exports commenced in 1938 and 1934 respectively. ${ }^{44}$ Battling to be granted the oil concession in Kuwait, the AIOC and the American company Gulf Oil eventually jointly founded the Kuwait Oil Company (KOC) in December 1934. The oil concession delineated all of Kuwait's territory as land available for oil explorations for the next seventy-five years. ${ }^{45}$ The oil companies negotiated a deal to pay the then-ruler, Shaykh Ahmad al-Jaber Al Sabah, "a royalty of three rupees per ton plus four annas in lieu of tax," which was at the time as little as 0.2 British pounds. ${ }^{46}$

Prior to the discovery of large oil deposits in Kuwait, it was known that bitumen seepages lay openly like little sticky, dark lakes amid a sea of sand at some locations in the desert. ${ }^{47}$ Shipbuilders in Kuwait used the viscous material or, alternatively, fish oil from Hadhramaut to seal ship planks as was also done, for instance, in Iraq. ${ }^{48}$ Petroleum and petroleum-derived products, however, were mostly known in the form of imported goods like lubricants and paraffin for oil lamps brought from India and, later, from the refinery in Abadan across the Gulf. ${ }^{49}$ Empty oil tins were in turn used as transport containers and measuring units for drinking water imported from the Shatt al Arab; a common sight that Kuwaiti sculptor Sami Mohammed captured in a bronze sculpture of a woman carrying such a water-filled oil tin (fig. 2.1). Petroleum products such as Pennzoil (lubricants) and Oilzum (motor oil) were prominently advertised on signs mounted on, for example,

\footnotetext{
${ }^{43}$ See Ronald W. Ferrier and James H. Bamberg, The History of the British Petroleum Company, vol. 1: The Developing Years 1901-1932; vol. 2: The Anglo-Iranian Years, 1928-1954 (Cambridge, UK: Cambridge University Press, 2009); James H. Bamberg, British Petroleum and Global Oil 1950-1975: The Challenge of Nationalism (Cambridge, UK: Cambridge University Press, 2000).

${ }^{44}$ In Iraq, the Turkish Petroleum Company, a multinational consortium of European and American firms, was in charge of the oil industry, its concessions and operations; in 1929 it was renamed the Iraq Petroleum Company. The same year, the Bahrain Petroleum Company was established in Canada by the Standard Oil Company of California.

${ }^{45}$ Mary C. van Pelt, “The Sheikdom of Kuwait," Middle East Journal 4, no. 1 (January 1950): 23.

${ }^{46}$ Elizabeth Monroe, “The Shaikhdom of Kuwait," International Affairs 30, no. 3 (July 1954): 274. Shaykh Ahmad (1885-1950) ruled from March 29, 1921 until his death on January 29, 1950.

${ }^{47}$ For the first photographs of oil in Kuwait, see Laura Hindelang, "Photographing Crude in the Desert. Sight and Sense among Oilmen," in The Life Worlds of Middle Eastern Oil, ed. Nelida Fuccaro and Mandana E. Limbert, Edinburgh: University of Edinburgh Press, forthcoming.

${ }^{48}$ Broeze, "Kuwait Before Oil," 153.

${ }^{49}$ Ministry of Energy, Electricity and Water, Water and Electricity in the State of Kuwait (Kuwait: Center for Research and Studies on Kuwait, 2005), 41.
} 


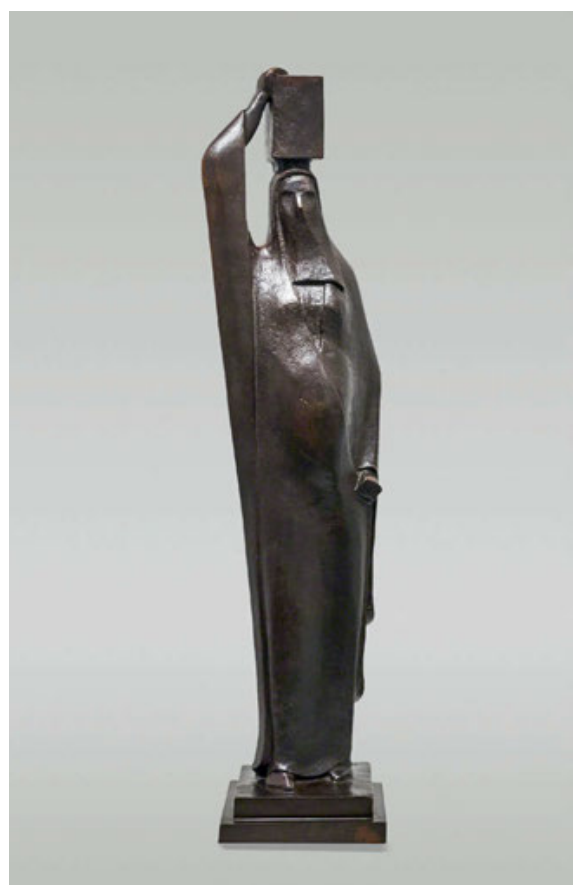

2.1 Sami Mohammed, The Water Carrier, undated. Bronze, $83.5 \times 18 \times 18 \mathrm{~cm}$. Barjeel Art Foundation.

Shamiya (Naif) Gate and Jahra Gate and, as postcards from the 1940s and 1950s show (figs. 2.2, 2.3).

The discovery of the massive Burgan Oil Field, around forty-five kilometers south of Kuwait City, occurred in February 1938, two years after drilling had started. Only a month earlier, oil in commercial quantities had been found in Saudi Arabia, where the American company CaliforniaArabian Standard Oil immediately exported its first tanker load in $1939 .^{50}$ It became quickly evident that Kuwait's petroleum was especially attractive because the deposits were enormous and extremely productive-they lay close to the surface and were pressurized enough to be tapped without pumping, making the production of oil fairly cheap. ${ }^{51}$ Nevertheless, due to restrictions on equipment and workforce during World War II, Kuwait's petroleum industrialization was suspended. Soon after the war had ended, Kuwait publicly celebrated its very first oil shipment to Britain in 1946. This event

${ }^{50}$ In Saudi Arabia, the American company California-Arabian Standard Oil gained the oil concession in 1933 and the Texas Oil Company took over 50 percent of its shares. From 1944 onward, the company was called Arabian-American Oil Company (ARAMCO) and, after nationalization between 1972 and 1980, eventually renamed Saudi Aramco in 1988.

${ }^{51}$ Stephen Longrigg, "The Economics and Politics of Oil in the Middle East," Journal of International Affairs 19, 1, special issue, The Arab World: Paths to Modernization (1965): 112-13. 


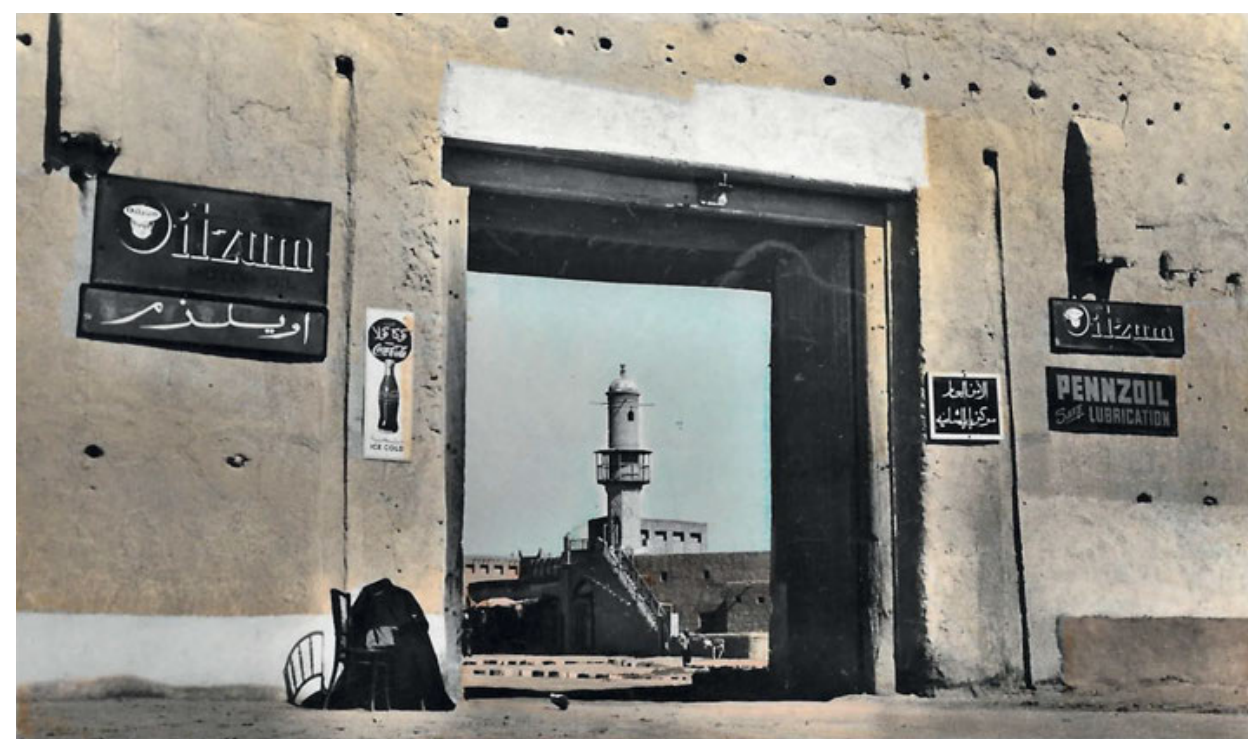

2.2 Shamiya (Naif) Gate with Pennzoil and Oilzum advertisements. Postcard mailed to the Netherlands in 1954 with a hand-colored photograph dating from the 1940s.

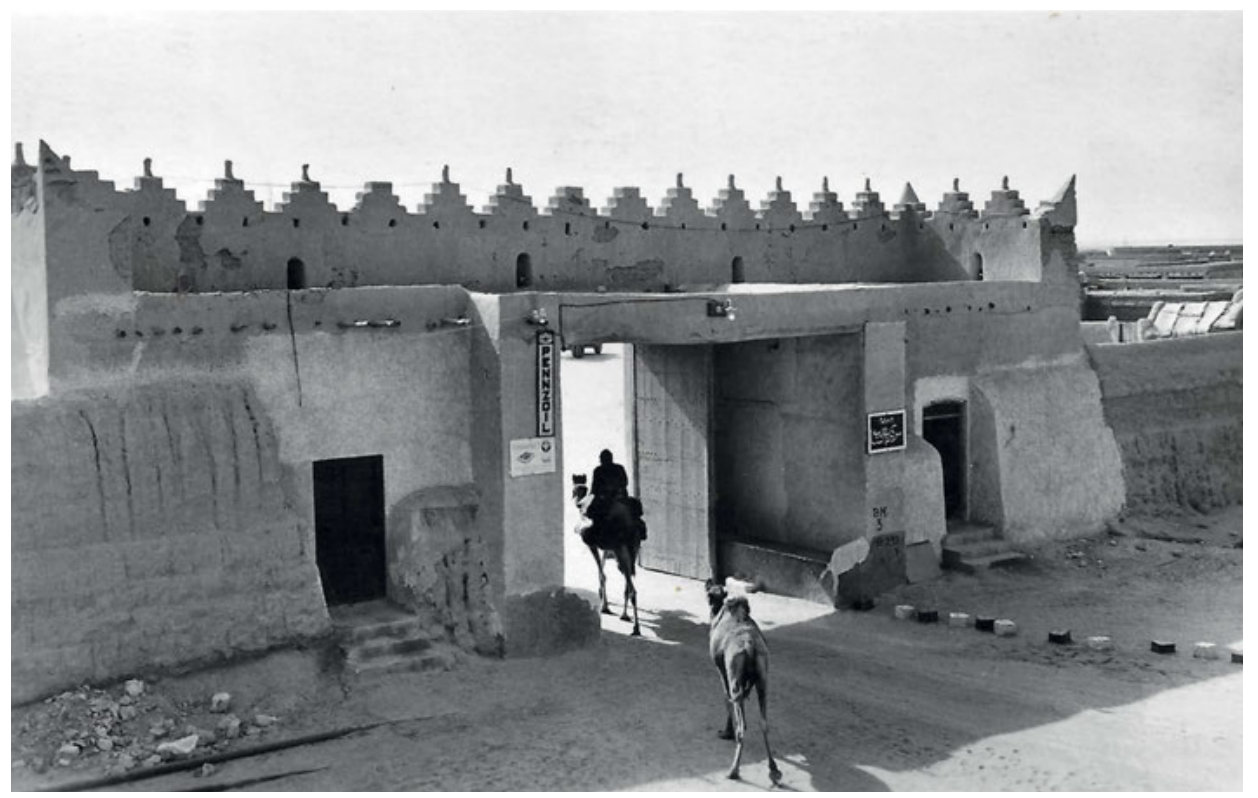

2.3 Jahra Gate with Pennzoil advertisement. Postcard from the 1950s with black-and-white photograph by Studio Badran, Kuwait City. 
marked the arrival of Kuwait's petro-modernity, as the flows of petroleum were clearly not restricted to the oil-producing sector alone.

Global demand for oil skyrocketed in the late 1940s, as war-torn economies picked up again after World War II. Meanwhile, Qatar had also struck petroleum (1940) and started exporting by $1949 .{ }^{52}$ At the time, the unequal oil concession deals stirred heavy discord, and not just in Kuwait. First the government of Venezuela (1948) and then Saudi Arabia (1950) reached a fifty-fifty oil profit-sharing agreement with their respective oil companies. Following closely, Kuwait, now ruled by Shaykh Abdullah al-Salem alMubarak Al Sabah, brokered a new fifty-fifty share deal with the Kuwait Oil Company by December 1951, securing an unprecedented income from oil revenues going straight to the account of the Shaykh and the Al Sabah as the sole contractor with the KOC. ${ }^{53}$ Consequently, although Abadan (and therefore Iran) had dominated oil production in the Gulf prior to World War II, it had never gained such substantial revenues due to the nature of the oil concession deal with the APOC at the time-and thus never the same international visibility.

In this already heated atmosphere, Iran had earlier that year decided to nationalize its petroleum industry, effectively expelling the AIOC (formerly APOC), which led to an international boycott of Iranian oil. Therefore, Britain lost one of its main oil suppliers overnight, and other oil-producing British allies, protectorates, and colonies had to jump in and satisfy the petroleum demand. This historical context stimulated an explosive increase of Kuwaiti oil production and, subsequently, a dramatic surge in income from oil revenues for the ruler's household. Consequently, the power balance between the Al Sabah and the merchant families radically shifted in favor of the former.

Initially, Kuwait was by far not the biggest oil producer in the world, nor did it have the biggest proven oil reserves. By 1955, however, it was producing 15 percent of the world's petroleum output. ${ }^{54}$ Given Kuwait's demographically and geographically small size in the early 1950s (around 100,000 people living in around 15,500 square kilometers, the size of the German federal state of Schleswig-Holstein), the amount of oil royalties per capita was enormous and unprecedented on a global scale, which stirred up much (orientalizing) excitement. As one British newspaper article from 1952 put it, "Kuwait will be, per head of

\footnotetext{
${ }^{52}$ An associate company of the multinational Iraq Petroleum Company (IPC) operated in Qatar and established the Petroleum Department of Qatar, which was in charge of concessions and operations. In the Trucial States (later the United Arab Emirates), the first onshore and offshore oil fields were opened up in 1958 and commenced exports in 1963 from Abu Dhabi. In charge of onshore operations was the IPC-subsidiary company, Petroleum Development (Trucial Coast), established in 1936. For the offshore explorations, another company was founded in the 1950s, the Abu Dhabi Marine Areas Ltd, which was jointly owned by British Petroleum and Compagnie Française des Pétroles (which later became Total).

${ }_{53}$ This salient story was immediately exploited in the international press; see, for example, "The Fabulously Rich Oilfield of Kuwait: Aspects New and Old of the Tiny State," Illustrated London News, December 22, 1951, 1030-31.

54 R. L. Banks, “Notes on a Visit to Kuwait," Town Planning Review 26 (April 1955): 49.
} 
its population, the richest state in the world. It is a transition more dramatic than any fable of the Arabian Nights." ${ }_{55}$ From 1950 to 1961, oil production increased from 17 million to 87 million metric tons, while state revenues jumped from 16 million to 467 million dollars. ${ }^{56}$ Within fewer than six years since the first oil export, the city-state of Kuwait had become the richest country in the world in per capita income. Suddenly Kuwait, like other Gulf states who followed in the 1960s and 1970s, was plunged into and intrinsically tied into the industrial capitalist world, as "wealth earned through oil revenues depends on world trade and fluctuating oil prices, as well as the capacity for energy consumption of the industrialized societies." ${ }^{57}$

\title{
2.3 Petro-States and the "Kuwaiti Model"
}

One of the immediate and tangible outcomes of oil production in Kuwait was a demographic surge. This surge was mostly caused by an influx of foreign skilled and unskilled labor to work in the oil industry, the quickly expanding government sector, and of course the construction industry. Visiting the country in 1953-54, young anthropologist Peter Lienhardt observed that:

\begin{abstract}
It was not, however, the Oil Company that was attracting most of the immigrants to Kuwait by this time, but rather the development of the city. Once an oil company had completed its installations, it was not a great employer of labour, unless there was a refinery, as in Bahrain. The city, on the other hand, had to produce all the services that had not been there before-metalled roads, pavements, sewers, piped water, electricity and telephone cables and new buildings-and to produce them all at once. ${ }^{58}$
\end{abstract}

And construction never seemed to cease. Workers, at the time mostly from other Arab and Gulf countries, were greatly attracted by "the highest money wage-scale in the Middle East" as well as free health care, education, and other services that the newly-established welfare state initially offered irrespective of citizenship..$^{59}$ By 1957, the first demographic census noted a doubling of the estimated total population of around 100,000 at the beginning of that decade, and 45 percent of the total population of 206,473 were nonKuwaiti. Four years later Kuwait already counted 321,621 inhabitants, the majority of which lived in Kuwait City itself..$^{60}$

\footnotetext{
${ }^{55}$ Lord Kinross, “The Richest State in the World," The Listener, December 11, 1952, 407 (italics in the original).

${ }^{56}$ Suhail Shuhaiber, "Social and Political Developments in Kuwait Prior to 1961”, in Slot, Kuwait, 105.

57 Khalaf and Hammoud, "The Emergence of the Oil Welfare State," 352.

${ }_{58}$ Peter Lienhardt, Disorientations: A Society in Flux: Kuwait in the 1950s (Reading: Ithaca Press, 1993), ed. Ahmed Al-Shahi, 35.

59 Suhail Shuhaiber, "Social and Political Developments in Kuwait Prior to 1961," in Slot, Kuwait, 105.

${ }^{60}$ While demographics were only estimated before 1957, proper national censuses were carried out in 1957, 1961, 1965, 1970, and 1975. See the Annual Statistical Abstract by the Ministry of Planning, Kuwait 1977,
} 
Because the growing number of people and oil revenues needed organization, in the logic of development and modernization, the government of Kuwait was institutionalized and expanded into a modern bureaucratic apparatus. A central goal of the government was to provide the (built) infrastructure for schooling, medical care, employment, and housing, all of which was offered for free to people living in Kuwait. Bedouin received incentives for sedentation. The influential merchants, who also had the best formal education, received important government posts. Former seamen and pearl divers found new employment in the lower ranks of the governmental institutions but also in the oil industry.

A fascinating testimony is Nasser Al-Othman's book With Their Bare Hands: The Story of the Oil Industry in Qatar, for which he collected interviews with Qatari men who had been the first to work in the oil industry. Several men recall shifting from pearling to working for the oil company in Qatar in the late 1930s and early 1940s-similar changes in professional biographies can be assumed in Kuwait, too. ${ }^{61}$ Many of the men interviewed explained their motivation due to the fact that aside from pearling, there was no other form of employment until the oil sector opened up and offered lucrative jobs. For example, Muhammad Muftah recalled: "I was paid 25 rupees for three months at sea compared with 30 rupees a month while working for the company." ${ }^{2}$ Not only in Qatar, but across the Gulf and in Kuwait, the workforce who once toiled the pearling ships often found new employment in the oil industry, underlining the fact that the oil companies also played a crucial role in the overall modernization and nation building process by providing jobs and income to the local population. ${ }^{63}$

After World War II, the Kuwaiti government began distributing the new wealth gained from oil revenues not only by establishing an impressive welfare state but also other channels. One important strategy was purchasing privately-owned land within the third town wall at increasingly inflated prices and then resettling the inhabitants within the newly emerging suburban neighborhoods outside the wall and the historical core on the basis of the first master plan, which had been introduced in 1952. To give an idea of the scope of this project, in 1961 the government still spent a third of its annual budget on land acquisitions, while 20 percent of the budget financed public works. ${ }^{64}$ Moreover, the government allocated land, developed and distributed it either as building plot or as

reprinted in Abdullah Abu-Ayyash, “Urban Development and Planning Strategies in Kuwait," International Journal of Urban and Regional Research 4, no. 4 (1980): 553-54 and table 1.

${ }^{61}$ See David Finnie, "Recruitment and Training of Labor: The Middle East Oil Industry," Middle East Journal 12, no. 2 (1958).

${ }^{62}$ Nasser Al-Othman, With Their Bare Hands: The Story of the Oil Industry in Qatar (London/New York: Longman, 1984), 91.

63 Bowen, “The Pearl Fisheries of the Persian Gulf," 179-80.

${ }^{64}$ Suhail Shuhaiber, "Social and Political Developments in Kuwait Prior to 1961," in Slot, Kuwait, 106-7. The author draws on the World Bank report The Economic Development of Kuwait (Baltimore: John Hopkins, 1965). 
state-built housing to Kuwaitis. To this day, "housing has become the currency through which the state physically transfers its wealth to its citizens," argues architect and urban researcher Sharifa Alshalfan. ${ }^{65}$

In this "oil mode of production," as social scientists Sulayman Khalaf and Hassan Hammoud call it, "wealth is not generated by productive social forces from within society itself, but it is distributed to the population by a new and continually expanding state bureaucratic apparatus." ${ }^{66}$ Here, the government as well as "economic life ... became almost entirely dependent on oil revenues, ... shaping in an accelerated form all aspects of social life in these 'old societies." ${ }^{67}$ This constellation, usually described as an oil rentier state, implies that the government is not dependent on the citizens for taxes and is also not politically accountable to them, but receives its budget to a large extent from oil revenues, of which it is the principal recipient. ${ }^{68}$ While only a few are involved in the generation of oil revenues, the majority are involved in its dissemination and spending. ${ }^{69}$ In an oil rentier state, citizens usually fully depend on the government, and therefore almost exclusively on the economic monopoly of oil production.

Eventually, a new Nationality Law, written in 1959 and amended in 1960, sharply defined and limited the conditions for entitlement to Kuwaiti citizenship and the access to much of the state's welfare system; one crucial factor was whether someone had lived within Kuwait (as delineated by the third town wall) prior to 1920, as the wall eventually served as the benchmark of citizenship entitlement, and hence also became a symbolic marker of Kuwaiti national identity. ${ }^{70}$ Another new law provided that all foreign companies operating in Kuwait had to be 51 percent Kuwaiti-owned and run jointly with a Kuwaiti partner. Peter Mansfield, a British political journalist visiting Kuwait in the late

\footnotetext{
${ }^{65}$ Sharifa Alshalfan, "The Aftermath of a Masterplan for Kuwait: An Exploration of the Forces that Shape Kuwait City," in "Wise Cities" in the Mediterranean? Challenges of Urban Sustainability, ed. Eckart Woertz (Barcelona: CIDOB edicions, 2018), 217-20, here 219; for a detailed discussion of housing and the Kuwaiti oil welfare state see Sharifa Alshalfan, The Right to Housing in Kuwait: An Urban Injustice in a Socially Just System, Kuwait Programm on Development, Governance and Globalisation in the Gulf States 28 (London: London School of Economics, 2013).

${ }^{66}$ Khalaf and Hammoud, "The Emergence of the Oil Welfare State," 350.

67 Ibid.

${ }^{68}$ First introduced by Hossein Mahdavy, the rentier state concept was subsequently refined and adapted to describe oil-producing and exporting (Arab) countries including Kuwait. Although much debated, it continues to be one of the dominant explanatory models in economic and political studies. Hossein Mahdavy, "The Pattern and Problems of Economic Development in Rentier States," in Studies in the Economic History of the Middle East: From the Rise of Islam to the Present Day, ed. Michael A. Cook (London: Oxford University Press, 1970), 428-67; Jacqueline S. Ismael, Kuwait: Dependency and Class in a Rentier State, 2nd ed. (Gainesville: University Press of Florida, [1982] 1993); Hazem Beblawi, “The Rentier State in the Arab World," in Beblawi; Luciani, The Rentier State; Giacomo Luciani, “Allocation vs. Production States: A Theoretical Framework," in Beblawi; Luciani, The Rentier State.

${ }^{69}$ See Hazem Beblawi, “The Rentier State in the Arab World," in Beblawi; Luciani, The Rentier State, 51.

70 See Fuccaro, "Pearl Towns and Early Oil Cities," 111.
} 
1950s, observed that "although Kuwait was physically changing at an astonishing pace in the 1950s and an inexorable shift was taking place in its population structure, the country was far from losing its individual character. On the contrary, this character was becoming stronger and more self-confident." ${ }^{11}$ Indeed, the 1950s provided for the nationalization or "Kuwaitization" of the economy and the country, which resulted in an overall enhancement of a Kuwaiti national identity. The evolving system of "reverse taxation"-whereby the government paid the citizens through direct payments, government jobs, public services, property, and other welfare benefits in combination with a protection scheme in order to prevent certain groups considered "alien" (such as expatriates, residents without Kuwaiti citizenship) from accessing many of the oil-funded benefits-became known as "Kuwaiti model"; with some modifications, it was adopted by the other Gulf states once they started oil production. ${ }^{72}$

Given the unprecedented speed and magnitude of change while moving from being a pre-oil community to being one of the world's most significant oil producers, the level of political and socioeconomic stability in Kuwait was remarkable but not unusual for petrostates during this earlier oil-producing period. ${ }^{73}$ In The Paradox of Plenty: Oil Booms and Petro-States (1997), Terry Lynn Karl has assessed the impact of oil booms, especially those occurring throughout the 1970s (of which Kuwait's 1950s boom is a forerunner), on oilexporting countries and found that many apparently diverse oil countries shared strong similarities. First, all of them came to depend heavily on the same commodity (oil) as their prime export product. Secondly, the development of the petroleum industry very often also coincided with state formation, making petroleum the common denominator: "The petro-state's technical and administrative resources, its symbolic content, its institutional separateness, and its own interests are most fundamentally shaped by its leading export activity [petroleum]," effectively interlinking the formation of a national identity also ideologically with oil. ${ }^{74}$ Thirdly, the petro-states had difficulties exerting political authority in a rentier setting. Fourthly and finally, despite the wealth of oil and especially oil revenues during oil booms, they all struggled to cope with managing the money and, subsequently, to adapt their expenditures from periods of abundance to periods of stagnation caused by fluctuations in the global oil market. Karl subsequently refined the resource curse theory for the case of petro-states-which today is referred to as the "oil curse" - in order to explain the harsh downsides of this phenomenon. ${ }^{75}$ In the mid-twentieth century, Kuwait,

\footnotetext{
${ }^{71}$ Peter Mansfield, Kuwait: Vanguard of the Gulf (London: Hutchinson, 1990), 47.

${ }^{72}$ Hazem Beblawi, "The Rentier State in the Arab World," in Beblawi; Luciani, The Rentier State, 54; E. R. Owen, “One Hundred Years of Middle Eastern Oil," Middle East Brief, no. 24 (2008): 3, accessed January 25, 2021, https://www.brandeis.edu/crown/publications/middle-east-briefs/pdfs/1-100/meb24.pdf.

73 Terry Lynn Karl, The Paradox of Plenty: Oil Booms and Petro-States, Studies in International Political Economy 26 (Berkeley: University of California Press, 1997), 58.

${ }^{74}$ Ibid., 46 (author's emphasis).

75 First introduced by Richard Auty in 1993, resource curse theory was subsequently applied to oil-producing countries in the work of Terry Lynn Karl in the 1990s. Richard M. Auty, Sustaining Development in
} 
Venezuela, and many other petro-states for the time being enjoyed affluence, capital, and political stability-with petroleum affirmatively infusing also much of their symbolic and thus visual representation.

Just as the Gulf states share the oil industry as common history, they used to share pearling as their socioeconomic history of boom and bust, as "pearls tied the Gulf to the regional and global market." 76 Victoria Hightower argues that "the pearl was a valuable commodity throughout history because it was low bulk, high value, and relatively easy to acquire and transport." 77 Pearls have always been a commodity and an export product, similar to petroleum. Birgit Krawitz's statement that "those for whom pearling was a lucrative business were globally networked entrepreneurs who met their peers in commercial metropolises" could equally serve to describe the subsequently emerging oil industry networks, which were of course much more corporate. ${ }^{78}$

Accordingly, in 1950s Kuwait it became petroleum, and no longer the complex debt system typical of the maritime pre-oil economy, that now held society together. ${ }^{79}$ Kuwait's riches no longer lay in the pearl banks out at sea but in fossil deposits underneath the desert sand, a shift from pearlescence to iridescence. It appears that the oil concessions and finally the successful launch of the oil industries across the Arab Gulf states came just in time to ease the life-threatening depression after the demise of the pearling industry. Kuwaiti historian Mohamad Abdul Hadi Jamal argues:

Had it not been for the discovery of oil during that period and the turning of big numbers of Kuwaitis
to work in the Oil Company as well as the flourishing of the commercial activity, it would have been
difficult to imagine the living conditions of Kuwaitis as a result of halting of the pearl diving business
and traveling to India. The discovery of oil has led, in a few years, to changing the life of Kuwaitis and

Mineral Economies: The Resource Curse Thesis (London: Routledge, 1993); Karl, The Paradox of Plenty. In current anthropological research, the oil curse is conceptualized as "the triple conjuncture in petro-states of stagnating social development and poverty; high conflict, often violent; and a tendency towards authoritarian regimes." The authors call it the "crazy curse" because of the paradox of oil money producing more of a "petro-curse" than a "petro-utopia." Stephen P. Reyna and Andrea Behrends, "The Crazy Curse and Crude Domination: Towards an Anthropology of Oil," in Crude Domination: An Anthropology of Oil, ed. Andrea Behrends, Stephen P. Reyna, and Günther Schlee (New York: Berghahn, 2011), 6.

${ }^{76}$ Victoria Hightower, "Pearls and the Southern Persian/Arabian Gulf: A Lesson in Sustainability”, Environmental History 18, no. 1 (2013): 46.

77 Ibid., 45.

${ }^{78}$ Birgit Krawietz, "The Sports Path Not Taken: Pearl Diving Heritage and Cosmopolitanism from Below," Sport, Ethics and Philosophy 14, no. 3 (2020): 11.

${ }^{79}$ In her comparative study of Venezuela, Iran, Nigeria, Algeria, Indonesia, and Norway, Terry Lynn Karl defines this radical substitution of former economic systems as a common denominator of petro-states. See Karl, The Paradox of Plenty. Jill Crystal also emphasizes that the political continuity and smoothness of transition "from pearling to petroleum" was achieved "because of oil, not despite it." See Crystal, Oil and Politics in the Gulf, 1 
their living style radically, after which the years of hardship had only become memories, and those who lived through them could hardly believe that such a nightmare had vanished. ${ }^{80}$

All social groups in Kuwait soon depended on the revenues from oil production, while the sea as livelihood (together with boatbuilding and pearling as professions) rapidly lost its importance. Conversely, the historical importance of imports was reinforced during the oil period to cover everything from basic supplies to the latest luxury goods. Through the diverse channels of pumping oil monies into society, the connecting maxim became partaking in the spending of this money. Kuwaiti society itself turned out to be implicit in fueling the demand (and justification) of oil production, as Kuwaitis immersed themselves in a lifestyle drenched in fossil energy, petroleum-derived products, and the iridescent attractions of petro-modernity.

All petro-states in the Gulf relied on foreign oil companies to initiate the capitalintensive and large-scale oil industry. These foreign firms became highly influential due to their monopolistic, internationally well-connected, and indispensable role in maintaining the petro-state. ${ }^{81}$ They claimed an ambivalent but powerful position within each Gulf state in the second half of the twentieth century. "On the one hand, they upheld and perpetuated the political units which had evolved and developed under British aegis; on the other, they acted as agents of major change. The two effects were mutually reinforcing," suggests Rosemarie Said Zahlan. ${ }^{82}$ In the mid-twentieth century, the major players in the Kuwaiti oil state were, besides the oil company, the ruling family as sole oil-revenue receiver and powerful distributor, and the still-influential merchant families. The latter would establish business empires with exclusive licenses for international brands, as, for example, Yousef Ahmed al-Ghanim, who was the Kuwaiti representative of BP products like Energol, which he advertised prominently in the Kuwaiti magazine al-Arabi ${ }^{83}$ Political power, however, had shifted in favor of the Al Sabah, who no longer depended (as much) on the merchants.

Most areas of social and economic life in Kuwait felt the impact of petroleum drastically and the two formerly most important environments of Kuwait, the sea and the desert, were radically subverted. As early as 1954, for instance, Peter Lienhardt noted that all of the old seafaring activities had substantially declined and that "only fishing continued to flourish in the old way," but that "even that had changed a little with the addition of diesel engines to convert the old sailing boats into launches." ${ }^{34}$ Harold Dickson, when explaining the sinking demand for pearls, suggested: "A girl to-day asks for a car, where formerly she

\footnotetext{
${ }^{80}$ Mohamad Abdul Hadi Jamal, The Old Crafts, Trades, and Commercial Activities in Kuwait (Kuwait: Center for Research and Studies on Kuwait, 2009), 118.

${ }^{81}$ Karl, The Paradox of Plenty, 47, 49-52.

82 Zahlan, The Making of the Modern Gulf States, 16.

${ }^{83}$ Back cover of the November 1964 issue of al-Arabī magazine, no. 72.

${ }^{84}$ Lienhardt, Disorientations: A Society in Flux, 94.
} 
craved a pearl necklace." 85 This suggestion is astonishing as it suggests a similar economic value between a pearl necklace and a car. Nevertheless, the observation indicates the sharp rise in petroleum demand, and the lifestyles it stimulated went somewhat hand in hand with a decreasing interest in traditional commodities such as pearls.

Around the same time, American Foreign Service officer Richard Sanger described the change stimulated by the petroleum (industry) of the Saudi Arabian desert landscape close to the Kuwaiti border:

For some distance inland the dunes and gravel plains, which a few years ago recorded only the footprints of infrequent caravans the unmistakable traces of Bedouin encampments, are crisscrossed with motor and railroad tracks, telephone wires, and pipe lines. Oil drums used as markers and road signs in English and Arabic give new character to the landscape in the daytime, while giant gas flares light up the landscape at night. ${ }^{86}$

Yet the field where petro-modernity struck most heavily and visibly, and where change was most felt and seen, was in the urban space of Kuwait. To assess the 1950s urban transformation and its resonance in urban visual culture, the following section provides an architectural and socio-spatial inventory of the town of Kuwait and the urban visual culture that existed until around the mid- to late 1940s.

\subsection{Pre-Oil Architecture and Visual Culture: An Inventory}

The bustling pre-oil town of Kuwait was nested between the Gulf and the 1920 town wall, between the sea and the desert. ${ }^{87}$ Given the extensive maritime economy, the waterfront (săhil) formed one of the busiest parts of the town. Here, ingoing and outgoing ships of all shapes and sizes were lined up, either propped up on the beach or moored along the shore, where low man-made coral walls functioned as breakwaters and created tidal basins for the dhows. Shipwrights were at work in the wharves and goods were loaded, unloaded, and inspected around the Customs House built in 1904 and the nearby al-furda market. Close by and roughly in the middle of the shoreline, Seif Palace stood on the site of the former Banū Khālid fort. It was considered the town house of the ruler, who

\footnotetext{
${ }^{85}$ Dickson, The Arab of the Desert, 485.

${ }^{86}$ Richard H. Sanger, The Arabian Peninsula (Ithaca: Cornell University Press, 1954), Photographs by courtesy of ARAMCO, California Texas Oil and Gulf Oil, 113; for a similar but not as illuminating description of Kuwait's desert see 164 .

${ }^{87}$ The following description is mainly based on the analysis of historical photographs from the KOC photographic archives as well as published photo collections, such as Basem E. Alloughani, Kuwait in Black and White: A Rare Collection of Pictures of Kuwait Before Oil (Kuwait: Xlibris, 2008) and 'Alī G. al-Ra'îs, Suwar min aswāq al-Kuwayt al-qadīma: 1916-1966 milādī [Pictures of the Souks of Old Kuwait: The Years 1916-1966] (al-Kuwayt: Markaz al-Buhūth wa-l-Dirāsāt al-Kuwaytiyya, 2017). The description also relies on these analyses of pre-oil Kuwait: Al-Nakib, Kuwait Transformed; Al-Nakib, "Inside a Gulf Port"; Broeze, "Kuwait Before Oil."
} 
otherwise lived in Dasman Palace at the northeastern edge of the town. ${ }^{88}$ In 1912, Barclay Raunkiær described Seif Palace as a large complex of various architectural styles indicative of the building's gradual adaptation and expansion. He recalled that it included the ruler's personal chambers, the facilities of his servants, and a governmental building, on the second floor of which there were large reception spaces with arcaded glass windows and furnished with European-style chairs and sofas. ${ }^{89}$ A small road called Seif Street (today the Arabian Gulf Road, a massive three-lane highway) led directly along the waterfront, and across the road was a line of storehouses, coffee shops, and imposing merchant houses, the largest houses in Kuwait besides the Al Sabah properties. ${ }^{90}$

Seif Palace also stimulated descriptions by Western travelers visiting Kuwait and these travel accounts shed light on the first spaces of accumulated image display and the kind of images that were present in Kuwait in the early twentieth century prior to the imageworld of petro-modernity. Hermann Burchardt noted the reception rooms decorated $a$ la franca with photographs of the English royal couple in December 1903, and in the 1930s Alain Villiers recounted: "Later in the day we had coffee with His Highness at his waterside palace, the one in the heart of the city where his grandfather, the Lion Mubarak, had decorated the bedrooms with ceilings filled with the lithographs of actresses and queens." ${ }^{91} \mathrm{He}$ also noted the presence of some photographs. ${ }^{92}$ Based on his extensive photography and postcard collections, Kuwaiti historian Ali AlRais ('Alī Ghulūm al-Ra' ìs) has shown that early postcards depicting Kuwait's harbor front and Bedouins at Safat Square were printed in Bombay as early as $1916 .{ }^{93}$ However, no permanent photographer resided in Kuwait until the mid-1930s.

Besides Seif Palace on the shoreline, the large souk was another focal point of Kuwait's morphology that extended from the sāhil to the town's center. Branching out landward from the port and waterfront alongside the souk were the honeycombed residential quarters. ${ }^{94}$ To the east and west lay the mercantile quarter Jibla and the maritime and

\footnotetext{
${ }^{88}$ See Al-Nakib, Kuwait Transformed, 117-18.

${ }^{89}$ Raunkiær, Through Wahhabiland on Camelback (1913), 33-34. Al-Nakib states that Seif Palace was built in the 1890s. Al-Nakib, Kuwait Transformed, 29. It is commonly said that the main diwan was built by Mubarak I. in 1905-06 and that the palace was substantially refurbished in 1917.

90 Broeze, "Kuwait Before Oil," 174.

${ }_{91}$ Annegret Nippa and Peter Herbstreuth, Along the Gulf: From Basra to Muscat: Photographs by Hermann Burchardt (Berlin: Hans Schiler, 2006), 62-63; Villiers, Sons of Sindbad, 312. In 1913, Barclay Raunkiær also saw and described this room's decoration in detail: “The ceiling is divided into panels by wooden fillets. Each panel is occupied by a polychrome lithograph, representing a young and appetizing [sic], including European, female beauty." Raunkiær, Through Wahhabiland on Camelback (1913), 34.

92 Alan Villiers, Sons of Sindbad: The Photographs (London: National Maritime Museum, 2006), 312.

93 Al-Ra'īs, Șuwar min aswāq al-Kuwayt al-qadìma, 22-23; see also 'Alī G. al-Ra'īs, Kuwait in Postcards (Kuwait: Center for Research and Studies on Kuwait, 2009).

${ }^{94}$ Farah Al-Nakib describes these residential quarters in great detail; see Al-Nakib, "Inside a Gulf Port," 218-21.
} 
pearling quarter Sharq, while Mirqab, which was developed by Nejdi Arabs employed in construction, extended from the souk southwestward.

Until the 1940s, when corrugated metal roofing sheets (locally called shinko) were added to provide shade, the souk was either open or covered by awnings made of wood or woven palm mats. Side by side and accessible by wooden doors, merchants' offices and vendors' shops clustered in specialized markets according to the kind of goods sold; there were, for instance, markets which specialized in corn, water, rugs and cloaks, or bookbinding. The ruler also conducted his everyday business in a two-story kiosk (kishk) within the souk..$^{95}$ Historical photographs show that, from the late 1940 s onward when oil revenues began sweeping the country, adverts for Western goods became more frequent and items such as refrigerators and gas-powered stoves were put on display. ${ }^{96}$ Cars, from Volkswagen to Chevrolet, also increasingly frequented the few wider streets.

According to one account, the first car (together with an Indian driver) had arrived in Kuwait as a gift to Shaykh Mubarak in $1912 .{ }^{97}$ Over the following two decades, a number of wealthy merchants also purchased cars with drivers, which resulted in a small fleet of taxis in the 1920s and a group of lorries servicing the roads to Saudi Arabia and Iraq during the 1930s. Around this time, car caravans were initiated to transport pilgrims in convoys across the desert from Kuwait to Mecca and Medina, a business which eventually became substituted by more comfortable air travel. On a larger scale, along with the expanding oil industry, privately owned cars rapidly increased in popularity and, of course, affordability in the late 1940s stimulating corresponding infrastructure of petrol stations, car workshops, and automobile salesrooms typical of twentieth-century petromodernity.

Another element of urban importance was Safat Square (Sāhat al-Ṣafät), which was connected with the market and the residential areas via several access points. As historian Farah Al-Nakib observes, "the Safat was the counterpoint to the sahel: whereas the latter was where the town interacted with the sea, the former was where the urban met the desert." ${ }^{98}$ From here toward the town wall there lay more or less open land for Bedouin tribesmen to camp in. Additional unbuilt spaces in the urban morphology included several cemeteries, which were located here and between residential areas.

Situated on an axis from Seif Palace to Naif Gate (part of the 1920 town wall), Safat Square lastingly shaped the urban morphology of Kuwait Town. The big open-air space was framed by small shops and served as the gathering point of three historic caravan routes. Caravans and Bedouins used the space to trade camels and other livestock and sell

\footnotetext{
95 Raunkiær, Through Wahhabiland on Camelback (1913), 35 and 50.

96 Al-Ra’īs, Șuwar min aswāq al-Kuwayt al-qadìma, 172-73.

97 Jamal, The Old Crafts, Trades, and Commercial Activities in Kuwait, 471-76.

98 Al-Nakib, "Inside a Gulf Port," 214 (italics in the original).
} 
goods such as brushwood, leather, and camel thorn. ${ }^{99}$ Public celebrations also took place here, including Shaykh Abdullah's coronation on February 25, 1950. ${ }^{100}$ From the 1930s onward, the Department of Finance, the police station, the British Bank of the Middle East, the Security Department, coffee shops and the baladiyya, the municipality founded in 1930, began framing the always-busy square. ${ }^{101}$ Later, car showrooms and rental agencies also opened here. Safat Square became notorious for being congested by cars and local taxis, which used the area both for parking and as a thoroughfare. Gradually evolving as an urban nexus in the 1950s, Safat emerged as a motif of Kuwait's petro-modernity in visual representations as will be discussed later.

Until its demolition in 1957, the third town wall effectively marked the boundary of Kuwait Town, enclosing an area of 7.5 square kilometers. The wall not only delineated jurisdiction but effectively shaped the (visual) urban form of both the pre-oil and the oil city, as the next chapter will analyze in detail. The wall comprised four gates and the mud-based construction was apparently a community effort to which every Kuwaiti was conscripted and thus became an important historical reference within the urban space and also in popular memory. ${ }^{102}$

Imagining a view of Kuwait from afar with its mainly one-story houses clustering over relatively flat terrain, the town's silhouette seems to have been rather plain. This included the town's religious buildings; according to historian Frank Broeze, "[the mosques' minarets] were such low structures that they were hardly visible above the houses of the city. Not even Kuwait's great mosque, close to the suq, possessed a dome or prominent minaret; instead it had a kind of architraved gate-tower over its entrance." 103 If anything, as Al-Nakib describes, "the roof of the palace became the highest point in the town, giving the ruler and his guards a clear view of the sea, port, market, and residential areas." ${ }^{104}$ However, on the ground, Al-Nakib argues that "it was the town harbor rather than a mosque, palace, or citadel that served as the locus of expansion, making it similar to port towns from the Mediterranean to the Red Sea and Indian Ocean." ${ }^{105}$ In summary, the town of Kuwait comprised a tightly knitted, walled-off urban fabric whose focal spaces were the waterfront with the Sief Palace, the souk, the residential areas, and open spaces such as Safat Square and several cemeteries.

\footnotetext{
${ }^{99}$ Villiers, Sons of Sindbad, 359. On the caravan routes see Al-Ragam, "Towards a Critique of an Architectural Nahdha," 34, 39-42.

100 Al-Ragam, “Towards a Critique of an Architectural Nahdha," 35.

${ }^{101}$ On the historical development of the baladiyya into an "agent of change in Kuwait" see ibid., 35-37, here 35 .

102 Abu-Hakima, The Modern History of Kuwait, 133.

${ }^{103}$ Broeze, "Kuwait Before Oil," 172 (italics in the original).

104 Al-Nakib, Kuwait Transformed, 31. The name is derived from al-saif, the Arabic word for seafront.

105 Al-Nakib, "Inside a Gulf Port," 210-11.
} 


\section{Vernacular Architecture}

Shifting from a distant horizontal viewpoint to a close-up perspective, the pre-oil, mostly domestic architecture of Kuwait can be characterized as follows: ${ }^{106}$ houses were clustered in quarters (farijj; pl. firjān) around a local mosque and a little square with a few shops. Given that the main means of transportation before the mid-1940s were going on foot or by donkey, streets consisted primarily of small lanes and blind alleys. The tight-knit arrangement was also influenced by the fact that building houses in dense clusters increased the available shade, which could be enjoyed on the outdoor benches, called maștaba, protruding from many houses.

Groups of houses inhabited by an extended family were usually built around a central courtyard. Most windows would have opened into the yard, which sometimes included "Sidr" trees and a cistern to collect rainwater. Most of the buildings in Kuwait were constructed using some kind of sun-dried mud bricks. More important structures like mosques, some merchant houses, and the Seif Palace were built using hard coral stone, which was locally mined at the shore. The often windowless outside walls were occasionally left unplastered, but were usually coated with locally found mud or gypsum.

The roofs of ordinary houses were lined by carved wooden or mud-brick parapets to shield the open rooftop space visually and to allow for air circulation. Wooden horizontal waterspouts or roof gutters (badgeer) pierced the outer walls to circulate cooling air but also to direct water from the flat roofs into the cisterns or onto the streets. The roof itself was supported by mangrove poles (locally known as jandals) usually imported from Lamu Island off the Kenyan coast or from the Rufiji Delta in today's Tanzania. Used as beams, their lengths determined the width of Kuwaiti houses. On top of these poles, mats made of reed or Iraqi date palm leaves held a mixture of mud and straw that formed the ceiling and roof as one. Teak wood imported from India was used in the pillars supporting the courtyard houses' verandas and for the richly carved wooden doors Kuwait and other Gulf towns were known for. The common architectural style, made up of building techniques, specific materials, and ornamentation found in wooden carvings (doors, furniture) constituted what can be called one aspect of the pre-oil urban visual culture prevailing in Kuwait that effectively shaped Kuwait's overall appearance, its image.

Pearls also played a role in this regard. In a way, the remains of pearling formed the sediment on which the modern Gulf cities were built on. Richard L. Bowen, a chemical engineer by profession who worked for the Arabian American Oil Company in Saudi Arabia between 1945 to 1947, reported the following story:

${ }^{106}$ For detailed descriptions of the vernacular pre-oil architecture in Kuwait and in the Gulf, see Ronald Lewcock and Zahra Freeth, Traditional Architecture in Kuwait and the Northern Gulf, Art and Archaeology Research Papers (London: United Bank of Kuwait, 1978), 15-24; Stephen Gardiner, Kuwait: The Making of a City (Burnt Mill: Longman, 1983), 16-19; Huda Al-Bahar, "Traditional Kuwaiti Houses," Mimar, no. 13 (1984); Evangelia S. Ali, "Retracing Old Kuwait," in Kuwait Arts and Architecture: A Collection of Essays, ed. Arlene Fullerton and Géza Fehérvári (Kuwait: Oriental, 1995); Al-Nakib, Kuwait Transformed, 54-69. 
When the refinery at Ras Tanura [in Saudi Arabia, completed 1945] was being built, a low hill was leveled by bulldozers. Cutting through many ancient graves they turned up a stone diving weight among the numerous bones and pottery. Between Jubail and Ras Tanura, several more ancient shell heaps have been located high on the beach. Some of these are composed entirely of the large platesized species of pearl oysters. ${ }^{107}$

Given that all Gulf states participated in pearling, bulldozers that demolished the old town of Kuwait during the 1950s likely encountered such pearling remains, too.

Overall, this vernacular style and method of building was practiced until well into the 1940s. As Alan Villiers reported in 1939, despite heavy rainfalls that had destroyed over 2,000 houses,

\begin{abstract}
this disaster had not brought about any improvement in the style of building. Houses were still without foundations, still only walls of coral stones. Here and there I saw new houses laced with Japanese cement, and some of these looked a little better. The habit of using cement was on the increase he [Nejdi, a Kuwaiti captain] said; but he doubted its value, for the local builders put too much sand in the cement. ${ }^{108}$
\end{abstract}

From these observations it can be established that imported cement was occasionally used in construction by the late 1930s. It is noteworthy that not only modern reinforced concrete (or cement) architecture relied on building material imports, but also pre-oil architecture depended heavily on imported goods. In addition, it was common for Kuwaiti architecture to be regularly renovated and even rebuilt after heavy rain, thus designating a certain temporality as characteristic concept of coastal architecture in the Gulf.

Western businesses were largely absent from Kuwait before the establishment of the KOC in 1934. Until that time, only a few Westerners had stayed for longer periods in Kuwait; among these were the British Political Agents, the staff of the American Mission, and oilmen engaged in prospecting oil and brokering licenses, such as the geologists Arnold Heim and Frank Holmes. ${ }^{109}$ However, until the first export of oil in 1946 and the subsequent incoming oil revenues, oil business was conducted outside Kuwait City in the oil company town of Ahmadi, around forty kilometers south of the capital, and "little of its impact was felt there." ${ }^{110}$ In Kuwait Town, the first two houses with strong Western architectural influence in terms of style, building materials, and construction method, were the Political Agency and the American Mission hospital. ${ }^{11}$ Some of the early civic buildings, including the baladiyya and the Departments of Finance and Public Security, projected the earliest shift in local architectural style, notably the embellishment of the façade and the roof parapet. ${ }^{112}$ In the late 1940s, Kuwait Town's urban form still consisted

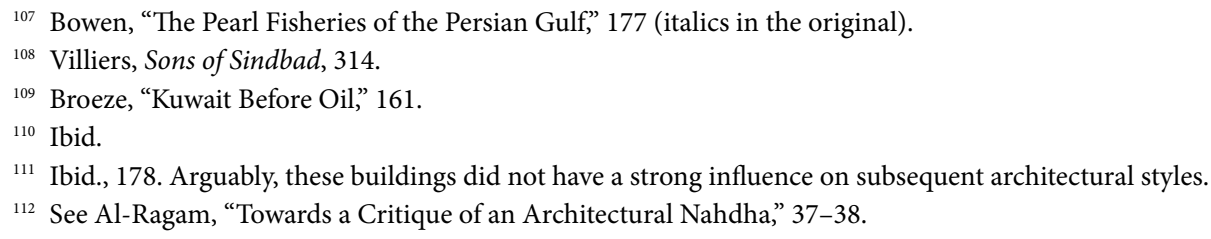


of a honeycombed cluster of low buildings of a fairly homogenous vernacular style, typical of the Gulf coast, that encompassed the historically grown focal points of the waterfront, the souk, and, in Kuwait especially, Safat Square.

\section{The Emergence of Visual Arts}

Besides the scarce appearance of photography and portrait lithographs as displayed at Sief Palace, Kuwait's pre-oil visual culture was rooted in material forms and cultural practices such as pearling, wood carvings, metal work, textiles, and in architecture-contexts where the visual and the material went hand in hand. ${ }^{113}$ However, "Western" art forms such as linear perspective drawing and easel painting as well as institutionalized art education were not unknown. Around 1936-37 when the oil explorations were in full swing, the formal school system in Kuwait was revised and art as an extracurricular subject was introduced at the prestigious Al Mubarakiyya School (al-Madrasa al-Mubārakiyya). ${ }^{114}$ Still, Tareq Sayid Rajab (1935-2016), a passionate painter, photographer, and later founder of the Tareq Rajab Museum displaying Islamic art, argued that "painting and drawing had virtually no role and except for the few pictures we saw in imported magazines, we had no idea at all," when he was a student at Al Mubarakiya in the late 1940s, early 1950s. Probably during the 1940s, the Kuwaiti government initiated a scholarship program to study abroad that allowed its recipients to obtain a formal art education, mostly in Egypt and Great Britain. The biography of Mojeb al-Dousari (1922-1956), today considered a pioneering artist and who later became the art teacher to Rajab at Al Mubarakiya, reflects these early educational opportunities for Kuwaitis. ${ }^{115}$ Although there was no full-fledged art scene in Kuwait during the first half of the twentieth century, the early rudimentary,

${ }^{113}$ For a broad overview of pre-oil material cultures of the Arabian Peninsula, see Ileana P. Baird and Hülya Yağcığlu, eds., All Things Arabia: Arabian Identity and Material Culture, Arts and Archaeology of the Islamic World 16 (Leiden/Boston: Brill, 2021).

${ }_{114}$ The interest of notable families in Kuwait to reform their children's education led to the opening of Al Mubarakiyya School on December 11, 1911. It became the first formal school in Kuwait with its own premises, a curriculum, and staff, many from Palestine and Egypt. Initially, only boys were allowed, but an additional girls' school was opened in 1937-38. Kuwait National Council for Culture, Arts and Letters, Mubarakiya School: 100 Years' History of Education in Kuwait (Kuwait: Kuwait National Council for Culture, Arts and Letters, 2011). On art education in Kuwait see Muayad H. Hussain, "Modern Art from Kuwait: Khalifa Qattan and Circulism" (PhD diss., University of Birmingham, 2012), accessed January 21, 2021, https://etheses.bham.ac.uk/id/eprint/3909/1/Hussain_12_PhD_v1.pdf, 30-33; “Kuwait”, in The Grove Encyclopedia of Islamic Art and Architecture, ed. Jonathan Bloom and Sheila Blair, 3 vols. vol. 2 (New York: Oxford University Press, 2009), 405.

115 Sultan S. Al Qassemi, “Correcting Misconceptions of the Gulf's Modern Art Movement," Al-Monitor, November 22, 2013, accessed January 22, 2021, https://www.al-monitor.com/pulse/originals/2013/11/ gulf-visual-arts-modern-indigenous-tradition-misconception.html; Tareq Sayid Rajab, Tareq Sayid Rajab and the Development of Fine Art in Kuwait (Kuwait: Tareq Rajab Museum, 2001), iii-iv. 
and later evolving art infrastructure can provide clues to understand assessments such as the following statement made by the Grove Encyclopedia of Islamic Art and Architecture that "the modern art movement in Kuwait is the oldest among those in the Arabian Peninsula." 116 Also Sultan Sooud Al Qassemi, art collector, educator, and founder of Barjeel Art Foundation, and the art historian Wijdan Ali have stressed Kuwait's historic role for the proliferation of modern art in the Gulf. ${ }^{117}$

A generation and more after al-Dousari, Khalifa Qattan (1934-2003), Sami Mohammed $\left({ }^{*} 1943\right)$, Munira Al-Kazi $\left({ }^{*} 1939\right)$, Abdullah Al Qassar (1941-2003), Ibrahim Ismail $\left({ }^{\star} 1945\right)$, Thuraya Al-Baqsami $\left({ }^{\star} 1952\right)$ and others were able to forge artistic careers as visual artists and sculptors and gained national and international attention to various degrees. ${ }^{118}$ Besides strong figurative tendencies among Kuwaiti artists, Surrealism was favored by Al Qassar and others, and Qattan developed his own style and aesthetic theory called Circulism. ${ }^{119}$

No comprehensive research has been done on the early modern history of visual arts in Kuwait so far. However, it is known that from the mid-twentieth century onward, governmental efforts to establish art education and an art scene in Kuwait increased. ${ }^{120}$ Besides the scholarships, of which also Rajab profited, the Department of Education focused on establishing professional artistic training opportunities and spaces for artists to work and exhibit, such as the Free Studio (al-marsam al-hurr) founded in 1960. In 1967, Sami Mohammed and others established the Kuwaiti Association of Plastic Arts. And that year or 1968, Khalifa Qattan initiated the Society of Formative Arts as an independent exhibition platform. ${ }^{121}$

In March 1969, Kuwait's, and in fact the Gulf's, first art gallery opened in the iconic Thunayan Al Ghanim Building on the roundabout leading to Fahad al-Salem Street with a show of works by Munira Al-Kazi (Kuwait) and Issam al-Said (Iraq). The Sultan Galleryfounded by the siblings Najat and Ghazi Sultan, she a teacher, he an architect-would continue to show "modern young Arab artists" and sometimes also Western artists, such as Andy Warhol in 1977, to create networks of artistic exchange across the Arab world and

\footnotetext{
116 "Kuwait," in The Grove Encyclopedia of Islamic Art and Architecture, ed. Jonathan Bloom and Sheila Blair vol. 2 (Oxford/New York: Oxford University Press, 2009), accessed February 2, 2021, https://www.oxfordreference.com/view/10.1093/acref/9780195309911.001.0001/acref-9780195309911-e-525?rskey=bSbVLs\&result $=1$.

117 "Kuwait," 405; Al Qassemi, “Correcting Misconceptions of the Gulf's Modern Art Movement” Wijdan Ali, Modern Islamic Art: Development and Continuity (Gainesville: University Press of Florida, 1997), 121, 123.

118 All of them exhibited in the Gulf and across the Arab World, at times even in Europe, the Soviet Union, or the US.

119 On Qattan and Circulism see Hussain, "Modern Art from Kuwait”; Anneka Lenssen, Sarah Rogers, and Nada M. Shabout, eds., Modern Art in the Arab World: Primary Documents (New York: Museum of Modern Art, 2017), "294. Circulism and Kinetics in Kuwait."

120 See Ali, Modern Islamic Art, 121-23.

${ }^{121}$ Hussain, "Modern Art from Kuwait," 44.
} 
beyond. ${ }^{122}$ Obviously, a thriving, even if small, local and regional art scene emerged in the second half of the twentieth century in Kuwait that was very well-connected. Its history still awaits comprehensive research efforts to bring it to light, especially as there have only recently been efforts to systematically collect modern artworks from the region. ${ }^{123}$

\subsection{As Petro-Modernity Unfolds, Urban Visual Culture Is Fueled}

In the mid-twentieth century, Kuwait City's fossil-fueled urban transformation and petro-modernity's image-world unfolded against this historical, architectural, and visual background, as the following three main chapters will show. The speed of urbanization and the magnitude of urban transformation from the late 1940s onward was completely unprecedented, all-encompassing, and radical, yet nevertheless part of a certain continuous urban and social renewal Kuwait was historically acquainted with. The proliferation of modern visual media in public and private spaces and the emergence of a vivid visual and architectural culture strongly enhanced an experience of change that coincided with the growth of an affluent consumerist society and the development of a governmental body that demanded national and international representation through a visual language of national symbols and other imagery. Furthermore, also the Kuwait Oil Company, which spearheaded the country's most important economy, felt the need to both legitimize its lucrative operations and fuel the consumption of petroleum through attractive (visual) narratives.

The rise of a broad urban visual culture that encompassed the visual arts and (vernacular) architecture amid the expanding petroleum business in the Gulf is neither a singular nor an accidental case to be made about Kuwait; rather, it has revealed itself to be emblematic of petro-modernity in the Gulf and elsewhere. Probably one of the best informed people on modern art in the Gulf, Al Qassemi has argued that, besides modern school systems, state art programs, and social open-mindedness, "another factor that contributed to the development of the region's visual arts industry was another industry altogether, the discovery of oil around the mid-20th century." ${ }^{124}$ As example, Al Qassemi discusses the Bahrain Petroleum Company's commission of (local) artists, such as the

${ }^{122}$ Sultan Gallery closed in 1990 during the Iraqi invasion until Farida Sultan, the siblings' younger sister, reopened it in 2006. Kristine Khouri has done extensive research on the gallery based on its archives. The results of which were first shown in an exhibition at Sultan Gallery titled The Founding Years (1969-1973): A Selection of Works from the Sultan Gallery Archives in 2012. Kristine Khouri, "Mapping Arab Art through the Sultan Gallery," ArteEast Quarterly, Spring 2014, accessed January 22, 2021, http://arteeast.org/quarterly/ mapping-arab-art-through-the-sultan-gallery/.

${ }^{123}$ Many works of Sami Mohammed are on display at the Kuwait Museum of Modern Art, which was opened in 2003. Most Kuwaiti artists mentioned here are today in the collection of the Barjeel Art Foundation in Sharjah, established in 2010; some are also in the collection of the Mathaf: Arab Museum of Modern Art in Doha, established also in 2010.

${ }^{124}$ Al Qassemi, “Correcting Misconceptions of the Gulf’s Modern Art Movement.” 


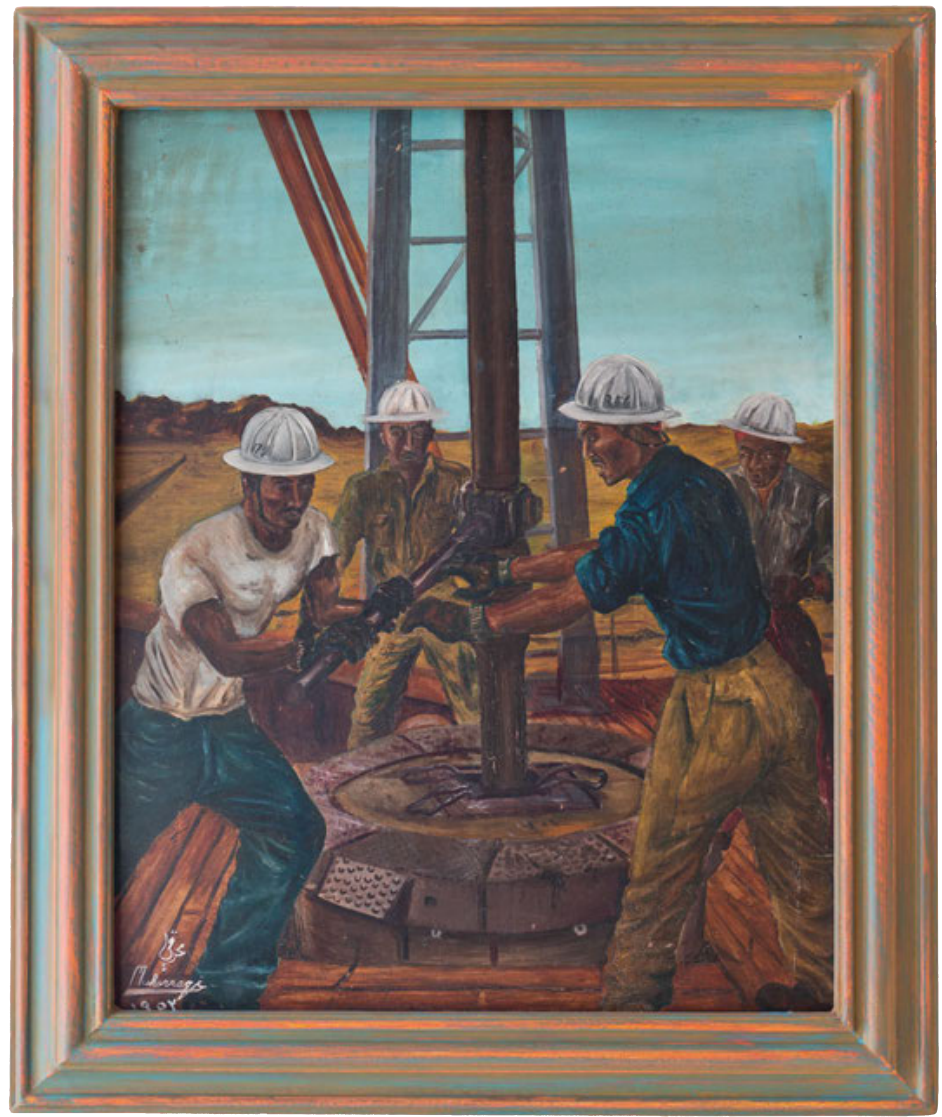

2.4 Adullah al-Muharraqi, Oil Exploration, 1953. Oil on hardboard, $75.5 \times 60.5 \mathrm{~cm}$. Mathaf: Arab Museum of Modern Art, Doha.

Bahraini Abdullah al-Muharraqi $\left.{ }^{*}{ }^{\star} 1939\right)$ for an oil painting in a figurative style that thematizes the oil industry, which is now in the collection of the Mathaf: Arab Museum of Modern Art in Doha (fig. 2.4). In al-Muharraqi's Oil Exploration (1953), we see four men working an oil drill at a well site in the desert. The artwork focuses on depicting the hard labor involved in the oil exploration and the harsh working conditions under the beaming sun and without any protection out in the desert. ${ }^{125}$

A similar story exists for Kuwait and the KOC: when parts of the collection of Neil Donaldson, a philatelic scholar and Gulf expert, were auctioned in spring 2018, the sale brought to light several hand-painted essays for an unpublished set of Kuwaiti stamps

${ }^{125}$ Ibid. Al Qassemi compares this painting to a similarly-themed oil painting by Saudi Arabian artist Abdul Halim Al Radwi (1939-2006) titled Extraction of Oil (1965). 
dating from 1960. ${ }^{126}$ According to the auction brief, Donaldson had made the design suggestions on behalf of the head of Kuwait's postal directorate, while Ramzi Kayello, who was a commercial artist who worked for the KOC, executed and painted the designs with motifs of a gazelle, the map of Kuwait, an oil tanker, and the ruler. ${ }^{127}$ Kayello, a Palestinian of Lebanese-Canadian citizenship born in Haifa, was later also in charge of a stamp design commemorating the twentieth anniversary of the first shipment of oil in 1966 with the image of an oil tanker and the portrait of Shaykh Ahmad al-Jaber Al Sabah, which seems to have been a joint project by the Kuwaiti government and the oil company. ${ }^{128}$

Overall, visual representations became the currency of the country in relation to the world and other petro-states and they effectively worked to simultaneously expose and hide the politics of petroleum behind a façade of progress, modernity, and urban transformation for much of the second half of the century. Images of the city transitioning into a petropolis became the poster child of the country and were crucial to the image of Kuwait (City) that different actors sought to curate, negotiate, manipulate, and aestheticize in a myriad of ways. The following main chapters unlock the ways in which the visual representations emerging in the context of Kuwait City's urban transformation created an image-world that reified Kuwait's petro-modernity. The starting point, one could say, was the process of creating the first master plan.

126 Auction house Christoph Gärtner, auction no. 39, February 2018, lot no. 6917, accessed January 22, 2021, https://www.auktionen-gaertner.de/?FTSearchHTML|Name=DetailsA\&Cat=GP \&UID=722045ABB07445B1C125821D006C822F\&Phase $=$ AUCTION \&Lang=DE \&DetailDB=PHILNET $/ G A E R T N E R / G P-$ KATAUK39\&CID=1\&SessionID=PxcTH-h25QT0y0zteSvH.

${ }_{127}$ Considered the founding father of philatelic history of the Arabian Gulf states and especially of Kuwait, Neil Donaldson (1920-2012) had worked for the Kuwait Oil Company from 1948 to 1967, although it is unclear in which capacity. See the two special issues on Neil Donaldson, al-Būsța (al-Posta), no. 23 (January 2012) and no. 24 (April 2012).

${ }^{128}$ Kuwait 1966, commem., MiNos. 323-24, referencing the catalog number of the stamp in Michel Gulf States Catalogue 2013. 2nd ed. (Unterschleißheim: Schwaneberger Verlag, 2012). Ramzi Kayello, artist's website, documents, accessed January 25, 2021, http://www.ramzikayelloartscapes.com/documents/CentralOfficeInterviewStamps.pdf. It remains unclear in which capacity Kayello worked for the KOC. 
